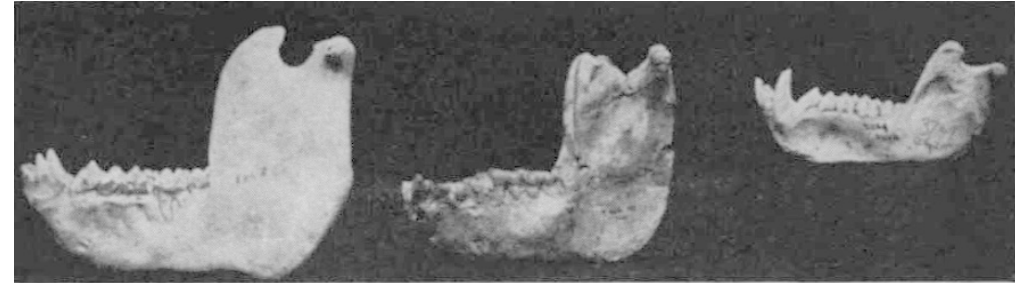

Fig. 7. The lower jaw of a female extinct giant baboon compared with the lower jaw of a male gorilla on the left and a male modern baboon on the right

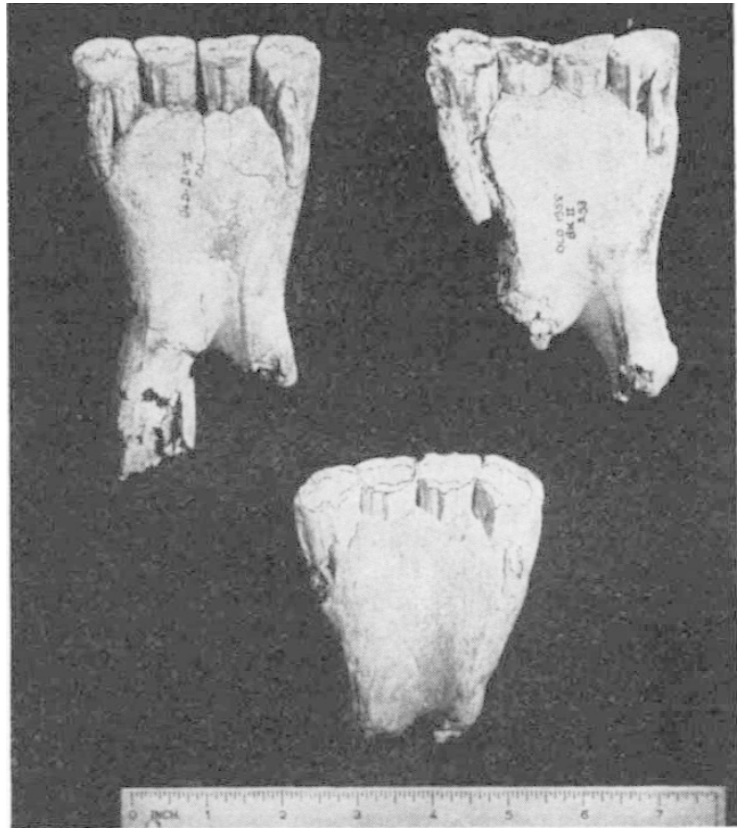

Fig. 8. The anterior part of the mandibles of two specimens of Eurygnathohippus compared with a cast of the fossil of the type specimen from South Africa

The fauna differs in no significant way from that of the slightly earlier $B K$ II site, but Sivatherium material is definitely more scarce, while there are a few broken pieces of tooth of Dinotherium bozasi. A detailed list will be issued at a later date.

The most outstanding find in this Chellean 2 living site is that of a fossilized flake tool made from hippopotamus ivory (Fig. 4, $a$ and $b$ ). This large flake of ivory shows a most marked and typical bulb of percussion, and the flake scar cuts right across the natural grain of the ivory. On the upper face the natural enamel of the tusk is preserved. There is clear evidence also of secondary trimming at the end opposite the butt. The tool was made from an upper canine of $H$. gorgops, and it constitutes the first record of a tool made from ivory, in any stage of the Handaxe culture, so far as I am aware.

The fossil fauna found during the recent work at Olduvai includes a fow specimens which are worthy of special mention here. Of outstanding importance are : (1) a tusk of the giant pig Afrochoerus nicoli which measures $785 \mathrm{~mm}$. on the curve (Fig. 5); (2) a tusk of Potomochoerus majus which measures $320 \mathrm{~mm}$. on the curve (see Fig. 6); (3) a lower jaw of a species of a gigantic baboon, possibly a new genus, which will be the subject of a special note in the near future (Fig. 7) ; (4) many specimens of the fossil which Van Hoepen called Eurygnathohippus, which seem to suggest that this represents a large Metaschizatherium (Fig. 8).

\title{
OBITUARIES
}

\section{Dr. J. C. Willis, F.R.S.}

DR. J. C. WILLIS, the veteran botanist, who died at Montreux on March 21 at the age of ninety, was the son of an American father and a Scottish mother. $\mathrm{He}$ was born at Birkenhead on February 20, 1868, and was educated at Liverpool and Cambridge. For two years after graduation he served as an assistant in the Botanical Department of the University of Glasgow, but at the age of twenty-eight he was appointed director of the Royal Botanic Gardens in Ceylon, a position that he occupied with distinction for fifteen years, afterwards becoming director of the Botanical Garden at Rio de Janeiro (1912-15).

During his tenure of the directorship of the Gardens in Ceylon, Willis did a great deal to organize and stimulate interest in tropical agxiculture, not least during his editorship of the Tropical Agriculturist and the Empire Cotton-growing Review. Willis was a forceful personality who will be chiefly remem- bered in connexion with three fields of activity. When at Ceylon he wrote his "Manual and Dictionary of the Flowering Plants and Ferns" which was based mainly upon Engler's "Die Naturlichen Pflanzenfamilien"; but in its earlier presentation about one-quarter of the text was devoted to principles of taxonomy, morphology and systems of classification that filled a real gap and for its period was quite excellent. This valuable reference work, now in its eighth edition, he handed over, a few years before his death, to the Bentham Moxham Trustees, which will ensure its continued usefulness and adequate revision.

The Ceylon flora is, like that of many other oceanic islands, especially rich in endemic species, the distribution of which attracted the attention of Willis, and from this developed his statistical analysis of types of distribution and the formulation of his 'Age and Area' hypothesis. If the main theme is now regarded as having only a very limited application, it served not merely as a great stimulus to ascertaining 
the relevant features of geographical distribution, but also focused attention on such facts as that endemics might be either ancient or modern, that rare species are far more numerous than common ones, and that monotypic genera are far more numerous than genera containing many species.

Willis believed that the statistical data, on which he based his hypothesis, belied natural selection and that evolution was merely a process of differentiation and a function of time. This was perhaps the more surprising since his most important contribution to descriptive botany was his monograph of the remarkable group of flowering plants known as the Podostemaceae. These grow only on the surface of rocks in rushing water and exhibit a remarkably varied and complex vegetative morphology with numerous features that, in the phraseology of that time, would be termed 'adaptations'. His contributions to science were recognized by his election to the Royal Society in 1919, and his distinction in the domain of tropical agriculture was marked by Harvard University conferring upon him an honorary doctorate when ten years earlier he had delivered lectures there on that subject.

E. J. SAlisbury

\section{Dr. J. A. Venn, C.M.G.}

MANY will have noted with regret the death on March 15 of John Archibald Venn, president of Queens' College, Cambridge, at the age of seventyfour. His father had been a Fellow of Gonville and Caius College, his grandfather and his great-greatgrandfather had been Fellows of Queens' College, and his death ends a distinguished family connexion with the academic life of Cambridge which lasted for six generations.

John Venn was born in 1883. From school at Eastbourne College he went up to Trinity College, Cambridge, where he studied history. After taking his degree in 1905, his interests led him to economics and the history of agriculture. These studies were interrupted by the First World War, in which he served as a captain in the Cambridgeshire Regiment for two years before being called to the Department of Food Production as statistician. In $192 \mathrm{I}$ he returned to Cambridge as Gilbey lecturer in the history and economics of agriculture, and he was also for some years an advisory officer of the Ministry of Agriculture.

In 1924 he became a member of Queens' College, with which his forebears had for so long been associated, and was elected a Fellow in 1927. Then, in 1932 when he was on leave in the Far East, came a cable from the governing body inviting him to become president of the College. His tenure of that office has been a most notable one. Under his wise and vigorous leadership, the size of the College has almost doubled-in accommodation, in the number of Fellows and in the number of undergraduates. In the President's Lodge he and Mrs. Venn (in 1906 he married the daughter of the late Sir William Ridgeway) kept open house and had always the warmest of welcome for all members of the College, past or present, who called there-and there were very many who did so.

In the affairs of the University of Cambridge Venn took a leading part. He was senior proctor in 1930-31, served on the Council of the Senate from 1934 until 1943 , and was vice-chancellor during the difficult war years 1941-43. Local government also claimed his attention; he was a magistrate and a member of the Town Council from 1934 until his death; he was chairman of the county Agricultural Wages Board, and a conservator of the River Cam. The Colonial Office sought his advice on many matters, notably in connexion with the sugar industry of British Guiana.

Under his direction the Farm Economics Branch of the University School of Agriculture developed in its first decade valuable techniques for the costing of typical farms, both generally, to reveal changing financial fortunes over time, and also in respect of specific problems such as sugar beet. Venn's work was always soundly based on his broad historical knowledge, as was shown by his review of the Agricultural Tribunal's Report in his book, "The Foundations of Agricultural Economics" (1924, revised 1933) and in his presidential address to the meeting of the Agricultural Economics Society, which was held in Queens' College in 1933. A regular attender of the meetings of the British Asso. ciation, he served on the council during 1934-39 and was president of Section M (Agriculture) in 1935.

Although agricultural economics was the subject which he taught in the University, he was primarily a historian and an antiquary. During 1933-35 he was president of the Cambridge Antiquarian Society. $\mathrm{He}$ and his father set themselves the unimaginable task of preparing a complete biographical register of all the men who had matriculated at the University up to the year 1900. The "Alumni Cantabrigienses" is a work of six volumes, printed in very small type; this work, and his contribution to agricultural economics, were recognized by the University with the award of the degree of doctor of letters.

That he was able to combine this time-consuming investigation with all the administrative duties which fell upon him as head of a college is a measure of his astonishing capacity for work. He gave meticulous attention to detail, yet this never for one moment obscured his vision of the wider issues. With his inoisive grasp of affairs went a youthfulness, both of mind and of body, which defied the years until mortal illness laid its hand upon him. It might seem that a life so full of serious activities could have afforded no time at all for relaxation. But it was far otherwise. In his younger days he was an enthusiastic tennis player, he invented a machine for bowling a cricket ball of any required pitch or break, he was a pioneer of motoring and a keen bird-watcher. There is no doubt, however, that from mid-life onwards his interests centred more and more upon the affairs of the College which he loved and served so well.

All these varied pursuits and his recollections of events associated with them made him an entertaining companion. One will remember best the evenings in College after dinner, and the occasions when some passing remark in the general conversation would provoke the comment that it was not always so; and then from his inexhaustible knowledge of the history of the University, intimately illuminated by the diaries of the Venn family, the company would be delighted by a few revealing glimpses of the- often shocking-past. This deep understanding and affection for the past, combined as it was with a frank recognition of the need for change, made John Venn a unique personality whose loss to Cambridge will be sadly felt.

J. A. RAMSAY 